ISSN 2080-1653

\author{
WIESŁAWA GIERAŃCZYK \\ Statistical Office in Bydgoszcz, Poland \\ MACIEJ RYCZKOWSKI \\ Statistical Office in Bydgoszcz, Poland
}

\title{
Public Statistics Resources as a Source for Research in Geography of Industry
}

\begin{abstract}
The article aims to present data resources for the needs of research in geography of industry in Poland. These sources can be independently obtained primary sources or secondary sources. Primary data have a unique value. They are collected for a specific purpose to solve a specific problem. They usually allow for a detailed description of the theme under investigation. As they are obtained directly from the surveyed entities during statistical research, they show timeliness and originality. In the research in geography of industry, primary data sources are used relatively rarely. It is mainly due to the time-consuming and costly nature of this type of research and the increasing difficulties in obtaining consent for research from respondents. Therefore, secondary data, which are the results of previous research, primarily by Statistics Poland, are especially popular. Statistics Poland, deals with issues useful from the point of view of the research in geography of industry, both in the form of surveys of the official statistics and as part of experimental studies. The article describes research carried out by Statistics Poland, which provides essential information about the industry and its location. Administrative data sources which may be helpful in this regard have also been mentioned. Public statistics has access to many of them. The area of interest of official statistics regarding data on industrial activities also refers to the data on the labour areas, which were created using the European version of the TTWA algorithm. The argument presented in this article proves that public statistics investigates a broad spectrum of phenomena related to industrial activities, and the results of these studies are and may be widely used by researchers in geography of industry.
\end{abstract}

Keywords: administrative data sources; commuting; geography of industry; labour market areas; public statistics sources

Received: 8 May 2018

Accepted: 21 July 2018

Suggested citation:

Gierańczyk, W., Ryczkowski, M. (2018). Public Statistics Resources as a Source for Research in Geography of Industry. Prace Komisji Geografii Przemysłu Polskiego Towarzystwa Geograficznego [Studies of the Industrial Geography Commission of the Polish Geographical Society], 32(4), 240-251. https://doi. org/10.24917/20801653.324.15

\section{INTRODUCTION}

Geography of industry is an academic discipline whose particular interest is the analysis of changes in factors and shaping of the spatial structure of industry of various sizes of enterprises, as well as spatial changes of their concentration forms (groups, 
centres, districts, complexes), including dispersed industry. The scope of research formulated in this way has been subjected to constant evolution because with the changes in the organisation of the socio-economic space, the thematic scope of the discipline is continually changing. While it was once an industrial plant, followed by a company, an industrial system and a production chain, now we are talking about global economic networks and, as a consequence, new forms of spatial organisation of industry. At the same time, difficulties in defining the primary research object are increasing. Indeed, industry is the sector of the economy in which - also under the influence of technological progress (especially new information and communication technologies) - the boundaries between industrial and service activities are getting blurred. It makes the attention of scientists more and more often focused on a functional and holistic approach to economic and geographic phenomena, and the problems of old geography of industry, in line with the global trend, is blending into the study of a holistically treated economic geography (Gierańczyk, 2014).

The evolution of geography of industry indicates that Polish researchers who are dealing with this discipline quickly react to changes in the surroundings and continuously update their research priorities. It is clearly shown by T. Rachwał's (2015) review of the themes of conferences devoted to the geography of industry organised under the aegis of the Industrial Geography Commission of the Polish Geographical Society. The object of interest of industrial geographers were both basic units of the spatial structure of industry (industrial plants), as well as forms of industry concentration (industrial centres and districts). The mechanisms of functioning of industry branches (e.g. agri-food industry) were analysed, as well as - in connection with systemic changes in Poland - the place and role of industry in the new management system and the transition from industrial to post-industrial development. An assessment was also made of the impact of transformation processes on the functioning of various types of industrial enterprises, as well as the condition of spatial and branch structures of industry.

In connection with Poland's accession to the European Union, much attention was paid to the transformation of industrial structures under the influence of integration processes. The problems of the functioning of industry in national and regional systems were also considered concerning the impact of various impulses flowing from the international environment. Progressive globalisation has guided research of geography of industry on the processes of servicing economy, in particular the tightening relationships between industry and dynamically developing service departments, such as communication, $R \& D$, education, finance or tourism, as well as the impact of industry on the development of the information society, the role and functions of industry in economic structure in conditions of growing importance of innovation and building a knowledge-based economy. Due to the change in the situation of the global economy, the impact of the crisis on the functioning of enterprises and changes in the spatial structures of the industry was also examined.

The eclectic nature of modern geography of industry (Stryjakiewicz, 2001) gives it a new value. For the work of industry geographers to fulfil this role, data is necessary to monitor the studied phenomena; processed with statistical methods and tools, the data will become useful information.

The article aims to present data sources that are useful from the point of view of the needs of the research in geography of industry in Poland, as well as present the 
selected phenomena describing industrial activity on the labour market based on the European version of the TTWA algorithm.

The European version of this algorithm was described in detail by Mike Coombs and Office for National Statistics (Coombes, 2015). The algorithm is based on the British method of Travel to Work Areas (TTWA), but it has been simplified compared to its earlier versions. The description of the algorithm can be found, for instance, in the Eurostat study (2015). In general, the construction of labour market areas is based on certain self-limitations of the areas. Gminas are combined in a specific way into clusters that potentially can create labour market areas (LMA). These self-restrictions apply to the minimum number of employees, the target size value, the level of self-limitation acceptable for larger clusters and their smallest acceptable size. The detailed way of determining the labour market areas in Poland (together with the encountered problems and solution proposals) has been described in the study of M. Ryczkowski and P. Stopiński (2018).

\section{PUBLIC STATISTICS RESOURCES FOR THE NEEDS OF RESEARCH IN GEOGRAPHY OF INDUSTRY}

Information in the public statistics system is obtained using statistical surveys, both representative and full, whose stages of implementation are established and well described in the literature (incl. Aczel, 2000; Paradysz, Dehnel, Gołata, Klimanek, Szymkowiak, Witkowska, Witkowski, 2004; Witkowski, Szymkowiak, Witkowska, 2009).

Data sources for research in geography of industry can be obtained independently (primary data) or can be reused. Primary data have a unique value. They are collected for a specific purpose to solve a specific problem. They usually allow for a detailed description of the theme under investigation. As they are obtained directly from the surveyed entities during statistical research, they present timeliness and originality. In research in geography of industry, primary sources of data are used relatively rarely. It is mainly due to the time-consuming and costly nature of this type of research and the increasing difficulties in obtaining consent for research from respondents. Therefore, secondary data, which are the results of previous research, are especially popular, especially those gathered by Statistics Poland (GUS). Statistics Poland deals with issues useful from the point of view of research in geography of industry, both within the framework of the program of statistical surveys of official statistics and as part of experimental studies.

As part of the program of statistical surveys of public statistics, many aspects of industrial activity are examined at various levels of spatial aggregation. As a result of this research, Statistics Poland is in possession of a rich set of information describing industrial activities. Due to the full range of data held, a detailed analysis of this one of the most critical segments of the national economy can be carried out. Data collected by Statistics Poland concern the production activity of industrial enterprises, finances, labour market, investment activities, foreign trade in industrial products, fuel and energy and material management, research and development, use of information and telecommunications technologies, and environmental protection. ${ }^{1}$

${ }^{1}$ More detailed information on individual thematic areas is available on Statistics Poland website (http://www.stat.gov.pl) - in publications, the Branch Knowledge Bases (DBW) and the Local Data Bank (BDL), as well as on the websites of statistical offices. 
Data on industrial activities can be obtained from various sources. However, care should be taken because the definitions, reference populations, the frequency of data collection and their representativeness may vary from study to study. The set of sources of data in geography of industry in Poland in a broad sense can include all studies in which data are collected in the Polish Classification of Activities - PKD [Polska Klasyfikacja Działalności] 2007 or at least contain information on PKD. These include, for example, labour market research, in particular such as Labour Force Survey - BAEL [Badanie Aktywności Ekonomicznej Ludności], National Economy Labour Force, National Population and Housing Census - NSP [Narodowy Spis Powszechny Ludności i Mieszkań], Remuneration Structure, Working Conditions and Demand for Labour.

In addition to research on the economic activity of population, censuses and other studies covering the labour market, it is necessary to distinguish research that focus on analysing information about industry. They form a possible set of data sources for geography of industry in Poland in a narrower sense. Relatively many studies of Statistics Poland can be mentioned here. Various aspects of industrial activities are included, such as Economic Survey - industry (AK-P), Business Survey - services (AK-U/m), Report on Economic Activity (DG-1), Report on revenues, costs and financial results and expenditures for fixed assets (F-01/I-01), Report on the status and movement of fixed assets (F-03), Production report (P-01), Report on production of goods and inventory (P-02), Annual company survey (SP) or Business Activity Report (SP-3).

Research included in the program of statistical surveys allows preparing, among others, information on industrial sold output for the current assessment of the production activity of industry, as well as the development of indicators of the condition of economy. Statistics Poland also researches the manufacturing of industrial products, turnover and new orders in industry, monitors changes in the shipbuilding and fuel industry, purchase and production of milk and milk products, as well as production, stocks and distribution of ethyl alcohol. In the field of interest of official statistics there is also the economic activities of industrial enterprises. One of the fundamental studies of Statistics Poland regarding industry is, for instance, the Statistical Yearbook of the Industry.

Separate research is devoted to the management of fuels and energy, including coal and lignite mining. Research is also being carried out to provide information on the electricity and heating sectors, enabling, among others, assessment of the functioning of the national power grid and its forecasting, as well as monitoring the level of the national energy security.

Statistics Poland also monitors issues related to the scientific and research potential, and studies the innovativeness of industrial enterprises. The increasing role of knowledge and innovation as driving forces for future development results in an increase in the demand for statistical data in this field, also in the context of assessing the level of innovation of the economy at national and regional level. One of the most critical factors of innovative activities used in the company's policy is research and development (R\&D). The R\&D departments that exist in most companies, as well as research and development units, are treasuries of knowledge, on whose effects and subsequent results competitiveness depends.

One of the dimensions of the effects of the R\&D and innovation activities is the protection of industrial property in Poland. Statistics Poland publishes information on 
patent statistics and intellectual property protection, with particular emphasis on the protection of industrial property in Poland (inventions, utility and industrial designs, trademarks, etc.). Applications and granted exclusive rights for inventions and utility designs in Poland are also monitored: in national and international mode, divided into domestic and foreign, and according to the International Patent Classification.

The public statistics also provides information on sectors showing the high intensity of the use of the R\&D results. Among other things, it acquires and publishes information on production, employment and foreign trade according to the levels of technology. Research is also being carried out to assess the research and economic potential in the field of biotechnology and nanotechnology.

For economic development, the impact of industry on the environment is also essential. Statistics Poland research includes, among others, monitoring of industrial wastewater and its treatment, pollution and air protection, industrial and post-production waste, ionising and non-ionising radiation, and industrial and communication noise.

The price indices of sold production of industry are published cyclically. Statistics Poland also conducts qualitative research on the economic situation in manufacturing. The indicator of the general business climate reflected the mood among entrepreneurs regarding their economic situation concerning the current and predicted overall economic situation.

An essential area of official statistics that includes industrial activities is labour market and remuneration surveys. The labour market covers all issues related to shaping labour supply and demand, and transactions of labour purchase and sales, i.e. employing workers. Labour demand is represented by employers offering jobs, while job seekers represent supply. In this area, the Central Statistical provides data, among others, on economic activity of the population, the employed in national economy, the unemployed and job seeking registered in employment offices, demand for work, working conditions, accidents at work, work permits for foreigners in Poland, as well as population flows related to employment. In the area of remuneration, the examined areas include, among others, wages in the national economy and their structure by occupation, as well as labour costs. In this respect, a critical study by Statistics Poland is "The structure of remuneration by profession".

Despite the multitude of studies covering various aspects of industrial activity, research carried out as part of the statistical survey program of official statistics does not exhaust the information needs of users of the data, including researchers in geography of industry. It stems from the fact that, given the burden of research for respondents and costs, Statistics Poland carries out the majority of research on samples. The sample size in the survey is usually too small for generalisations to be made for small territorial units. Moreover, in geography of industry, the research problems refer to spatial systems. It is indicated by the generally accepted definition of geography of industry proposed by S. Misztal and Z. Zioło (1998) which states that: "Geography of industry is a scientific discipline dealing with spatial aspects (properties and problems) of economic activities, involving the extraction of raw materials and their processing into production and consumption goods, as well as the provision of repair services". 


\section{ADMINISTRATIVE DATA RESOURCE AS A SOURCE OF DATA FOR THE NEEDS OF RESEARCH IN GEOGRAPHY OF INDUSTRY}

Statistical surveys of official statistics covering a broad substantive scope of the analysed issues are costly. Their implementation is connected with a very high burden on respondents and the resulting increase in the number of missing answers and refusals to complete the questionnaire, even with the use of such methods of collecting information as CATI2 or CAWI3.

The use of administrative registers may provide information on the low level of aggregation with high frequency. Hence, in many countries, public statistics are increasingly assisted by administrative sources to examine the processes, phenomena and factors that affect the situation and trends on the financial market, the health of the population, and updates the research coverage (Paradysz, 2007; Komisja Europejska, 2011). Also in Poland, administrative systems are increasingly used as a source of data (Komisja Europejska, 2011; Gołata, 2012; Dehnel, Gołata, 2012; Ryczkowski, 2016). For example, A. Młodak (2014) pointed out the importance of using administrative registers to study commuting. Commuting is, in turn, an indispensable element for the construction of labour market areas. From the point of view of business statistics and geography of industry, registers created by the Ministry of Finance and the Social Insurance Institution seem particularly valuable. It is because they contain, among others, information about such variables as the TERYT symbol, PKD 2007 section, income and net income, cost and number of employees.

The experimental study, which was part of a research project entitled "Development of methodology and estimation of the number of employed in national economy by place of residence and main workplace at the NUTS level 4, registered unemployment rate at the NUTS level 5, and gross remuneration measure at the NUTS level 4", which was conducted with the participation of employees of the Statistical Office in Bydgoszcz who specialise in labour market research, indicates that administrative data is an excellent source of information about employees by economic sectors. The functional information obtained on the basis of this data at the lowest level of the administrative division, i.e. gminas, provide information on the spatial distribution of the employed in industry (Fig. 1) and the role of the industrial sector in the economy of individual local and regional systems (Fig. 2).

As it appears from the data presented in Fig. 1 and 2, in many Polish gminas, especially in the western part of Poland, the role of industry in employment structure is so significant that it is possible to indicate the dominant role of this function in the economic structure. The enterprises and industrial plants located on their premises create jobs, the management of which is often related to specific competencies of the workforce. The mobility of production factors plays a vital role in meeting the demand for labour. The flows of employees are described by the labour market theories, which indicate that in the modern market economy, the decision on the place where the work is undertaken is determined by both micro- and macroeconomic conditions (Jarmołowicz, Knapińska, 2011).

Relations between the place of work and the place of residence are the subject of public statistics interest. The result of the research carried out with the participation of

\footnotetext{
${ }^{2}$ Computer-Assisted Telephone Interview.

${ }^{3}$ Computer-Assisted Web Interview.
} 
Fig. 1. Employment in industry in 2017 (as of June)

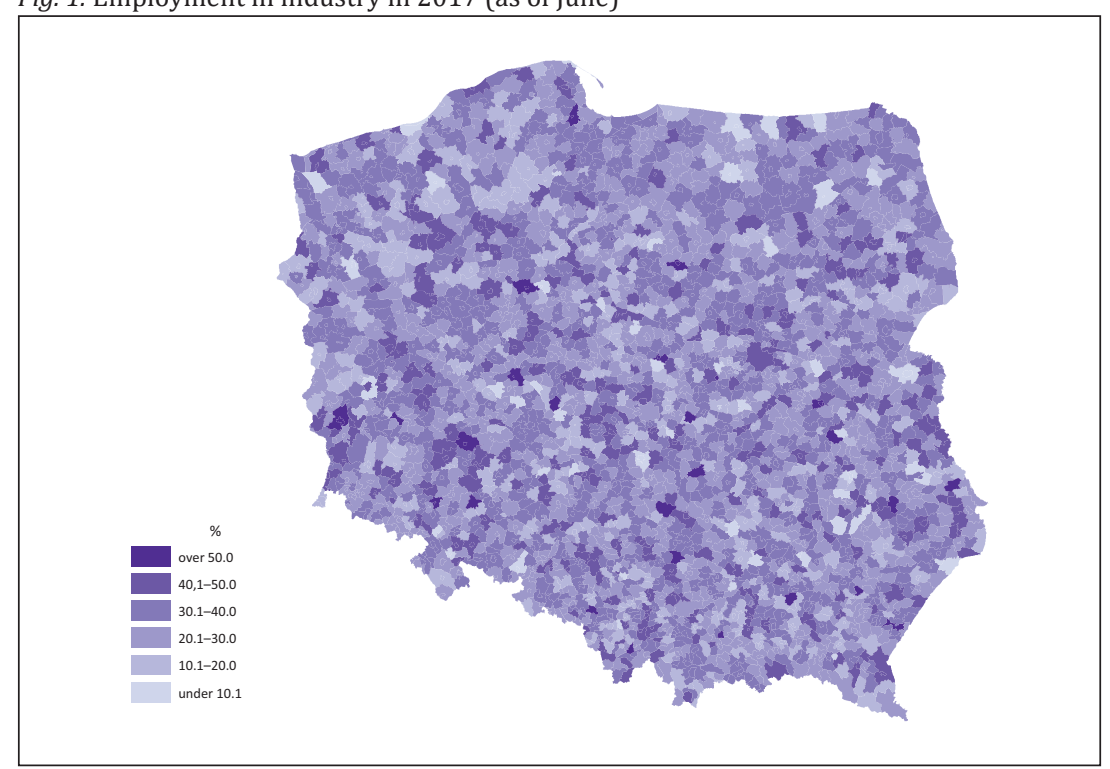

Source: own work based on experimental data from the study "Development of methodology and estimation of the number of employed in national economy by place of residence and main workplace at the NUTS level 4 , registered unemployment rate at the NUTS level 5, and gross remuneration measure at the NUTS level 4"

Fig. 2. Functional character of gminas in 2017 (as of June)

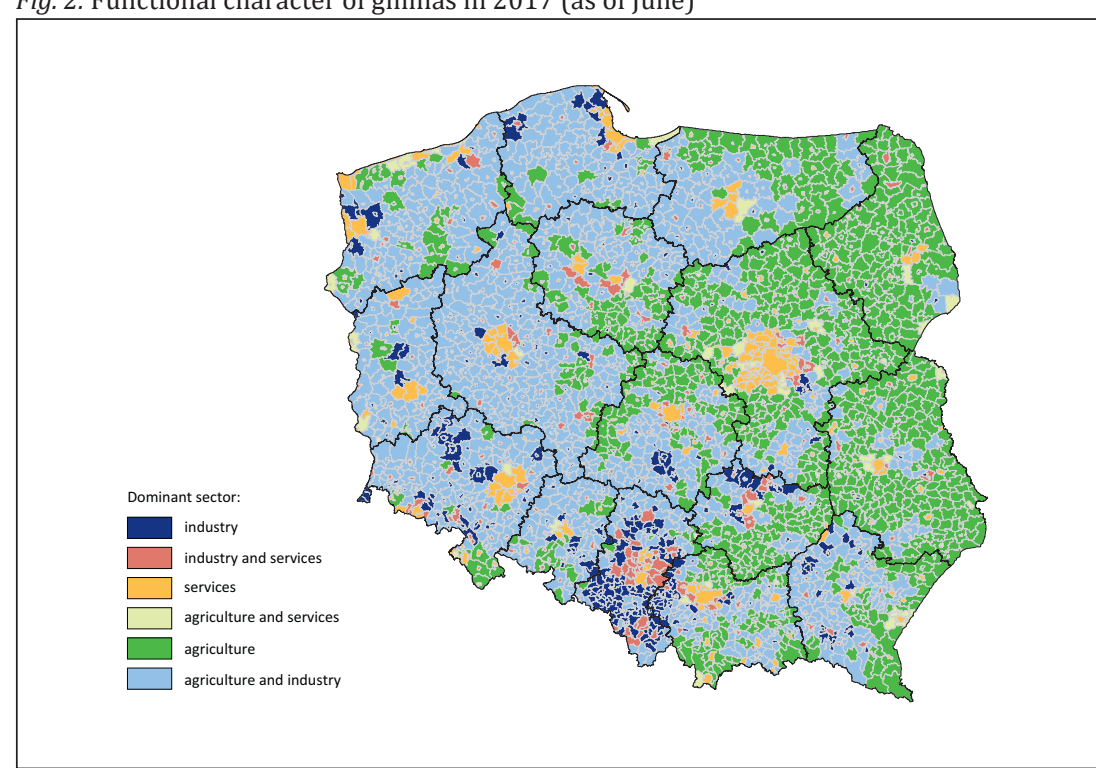

Source: own work based on experimental data from the study "Development of methodology and estimation of the number of employed in the national economy by the place of residence and main workplace at the NUTS level 4, registered unemployment rate at the NUTS level 5, and gross remuneration measure at the NUTS level 4". The criterion for selecting the dominant sector/sectors was the percentage share of the inhabitants of a given gmina working in a given sector or group of sectors 
employees of the Statistical Office in Bydgoszcz was the delimitation of labour market areas (LMA) in Poland based on the data on commuting. The methodology used was developed by Eurostat, together with the specially appointed working groups consisting of representatives of the EU Member States.

The LMA concept was initiated in the United Kingdom and Italy. It originated in no small extent from the idea of a functional impact of urbanised areas on the surroundings. It is based on the demand-supply interaction between individual areas. As a result, a comprehensive approach to the LMA is critical, e.g. for shaping regional development strategies. Indeed, this issue is of great practical importance and is the subject of research both in Poland (Gruchociak, 2012, 2013, 2015; Wdowicka, 2016) and in many other countries (Casado-Diaz, Coombes, 2011; Franconi, D'alò, Ichim, 2016; Kropp, Schwengler, 2016; Stimson, Mitchell, Flanagan, Baum, Tung-Kai, 2016).

In general, the delimitation of the labour market areas is based on the designation of an area in which as many people as possible live and at the same time work, not crossing their borders during commuting. The LMA can be understood as an economically integrated territory in which residents can find jobs at a reasonable distance from their place of residence or can change jobs without changing their place of residence. The methodology adapted by the researchers from the Statistical Office in Bydgoszcz was based on certain self-limitations of unit areas (the data on gminas was used in the algorithm). Gminas were combined in a specific way into clusters that potentially could create LMAs. These self-limitations apply to the minimum number of employees, the target value of the size of the cluster (i.e. the minimum acceptable level of self-limitation), the level of self-limitation acceptable for larger clusters and its smallest acceptable size. Self-limitation should be understood as a smaller value of the labour supply indicator in a given area (the relation of the number of people living and working there to the number of inhabitants) and the demand index (the relation of the number of people living and working there to the number of jobs in that area). A detailed way to determine labour market areas in Poland has been described in the study of M. Ryczkowski and P. Stopiński (2018).

Practical interest in functional areas (Carlquist, 2006; Młodak, 2012; Śleszyński, 2013) results, among others, from research indicating the relationship between the situation on the regional labour market and prosperity. M. Ręklewski and M. Ryczkowski (2016) argue that with the improvement of the situation on the regional labour market, the quality of life in Poland is improving.

The division into labour market areas is an alternative to the administrative-territorial divisions of the country and surveys of clusters of economic activities, including industrial ones. In contrast to standard nomenclatures and classifications, the LMA is not based on historical and geographical conditions, but is delimited through the study of socio-economic characteristics. The need to distinguish LMA was developed because regions of the administrative division of the country do not coincide with naturally arising functional areas.

Labour market areas may be applied in the research that is in the sphere of interest of geography of industry. The element of the functional structure of the employed, presented in Figure 3, seems to be an interesting application example of the concept of functional areas, because the spatial distribution of industry does not necessarily coincide with the administrative division of the country. It seems that functional areas 
Fig. 3. Functional nature of the labour market areas in 2017 (as of June)

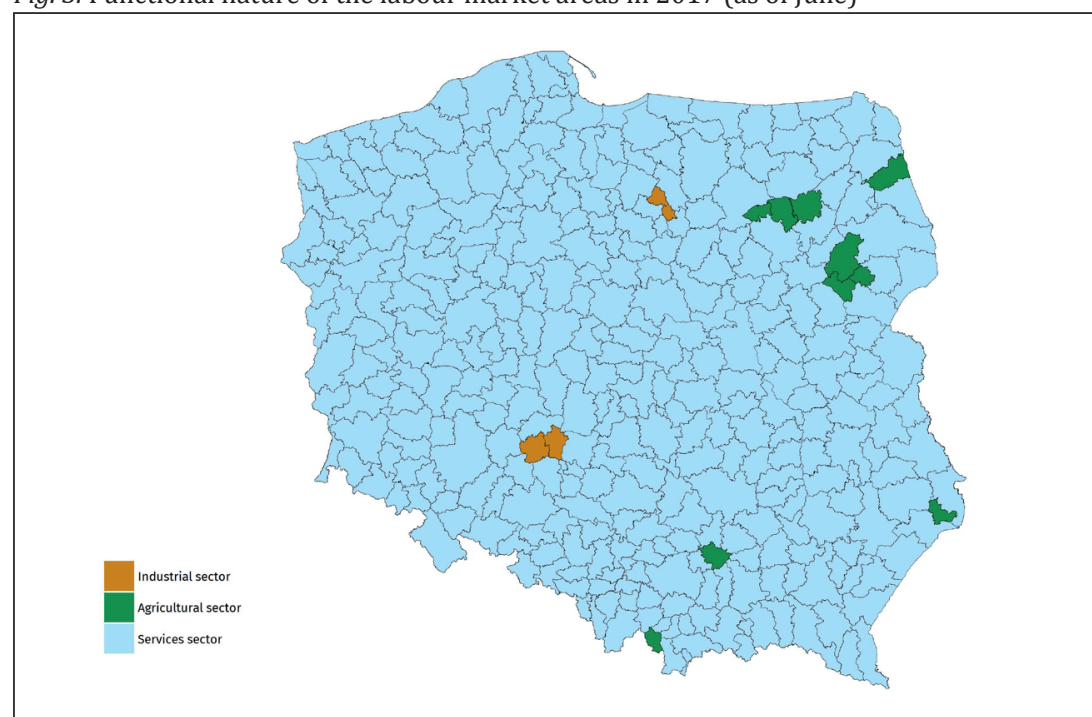

Source: own work based on a preliminary survey entitled "Application of the EU methodology to define labour market areas in Poland"

are more suitable for this purpose, among which the labour market areas are one of the options. In the vast majority of the labour market areas, the service sector dominates.

As it appears from the above, the data from administrative registers have numerous advantages. They include low costs of obtaining them, low or zero responders' load, regularity in obtaining data, and high coverage of the surveyed population. Nevertheless, the increasing use of administrative sources (including possible research in the sphere of interest of geography of industry) tends to draw attention to the fact that, in addition to many of their advantages, they also have disadvantages. These include, in particular, different definitions in the administrative registers from those used in official statistics, and the scope of information limited to registration purposes. Besides, administrative records often have incorrect or missing data. In the case of data combination, their accuracy, timeliness and frequency may need to be harmonised with the surveys conducted by public statistics. Without such adjustment measures, the indicated differences may be a potential source of disturbances in the results obtained (Ryczkowski, 2015).

\section{CONCLUSIONS}

This article discusses the data sources relevant to research in geography of industry, with particular emphasis on secondary data. The conducted study proves that public statistics investigates a broad spectrum of phenomena related to industrial activities, and researchers in geography of industry widely use the results of this research. A significant limitation of statistics provided by Statistics Poland is their availability in local systems. To meet these expectations, public statistics undertakes work on obtaining data, including data from administrative sources, that provide essential information about industry and its location. The studies carried out so far indicate high usefulness of 
this type of data sets and their applicability in delimiting labour market areas, i.e. functional areas of a socio-economic nature. This article can, therefore, play an essential role in the development of regional statistics and geography of industry.

\section{References}

Aczel, A.D. (2000). Statystyka $w$ zarządzaniu. Pełny wykład [Statistics in management. Full lecture]. Warszawa: Wydawnictwo Naukowe PWN.

Carlquist, T. (2006). Larger Urban Zones in the URBAN AUDIT Programme. In: J. Dziechciarz (ed.). 25th SCORUS Conference on Regional and Urban Statistics and Research. Globalization Impact on Regional and Urban Statistics. Publishing House of the Wrocław University of Economics.

Casado-Diaz, J.M., Coombes, M. (2011). The delineation of 21st century local Latour market areas: a critical review and a research agenda. Boletín de la Asociación de Geógrafos Españoles, 57, 7-32.

Coombes, M., Office for National Statistics (2015) (2018, 8 May). Travel to Work Areas. Pozyskano z www.ncl.ac.uk/media/wwwnclacuk/curds/files/RR2015-05.pdf

Dehnel, G., Gołata, E. (2012). Wykorzystanie rejestrów administracyjnych w statystyce przedsiębiorstw [The use of administrative registers in business statistics. Zeszyty naukowe Wydawnictwa Uniwersytetu Ekonomicznego w Poznaniu, 227.

Eurostat (2015) (2018, 8 May). Task Force. Harmonised Labour Market Areas. Final Report. Pozyskano z https://ec.europa.eu/eurostat/cros/system/files/Task\%20Force\%20on\%20 LMA\%20Final\%20Report.pdf_en

Franconi, L., D'alò, M., Ichim, D. (2016) (2018, 8 May). Istat Implementation of the Algorithm to Develop Labour Market Areas, https://www.istat.it/en/files/2016/03/Description-of-theLabourMarketAreas-algorithm.pdf.

Gierańczyk, W. (2014). Economic situation in the manufacturing sector as an example of modern research in industrial geography in Poland. Prace Komisji Geografii Przemysłu Polskiego Towarzystwa Geograficznego [Studies of the Industrial Geography Commission of the Polish Geographical Society], 25, 25-55.

Gołata, E. (2012). Estymacja charakterystyk przedsiębiorstw wspomagana zasobami rejestrów administracyjnych [Estimation of enterprise characteristics supported by administrative register resources]. Zeszyty naukowe Wydawnictwa Uniwersytetu Ekonomicznego w Poznaniu, 227.

Gruchociak, H. (2012). Delimitacja lokalnych rynków pracy w Polsce [Delimitation of local labour markets in Poland]. Przegląd Statystyczny, 2, 277-297.

Gruchociak, H. (2013). Delimitacja lokalnych rynków pracy w Polsce na podstawie danych [Delimitation of local labour markets in Poland based on data]. Prace Naukowe Uniwersytetu Ekonomicznego we Wrocławiu, 20(278), 343-350.

Gruchociak, H. (2015). Porównanie struktury lokalnych rynków pracy wyznaczonych przy wykorzystaniu różnych metod w Polsce w latach 2006 i 2011 [Comparison of the structure of local labour markets determined using various methods in Poland in 2006 and 2011]. Prace Naukowe Uniwersytetu Ekonomicznego we Wrocławiu, 385, 111-119.

Jarmołowicz, W., Knapińska, M. (2011). Współczesne teorie rynku pracy a mobilność i przepływy pracowników w dobie globalizacji [Contemporary theories of the labour market versus mobility and flows of employees in the era of globalisation]. Zeszyty Naukowe Polskiego Towarzystwa Ekonomicznego, 9.

Komisja Europejska (2011). Wykorzystanie danych administracyjnych w statystyce przedsiębiorstw. Raport końcowy z wdrażania akcji przeprowadzonej w terminie od 01.11.2009 do 28.02.2011 w ramach umowy o dotację nr 30121.2009.004-2009.807 [Use of administrative data in enterprise statistics, Final report on the implementation of the action carried out from 1 November 2009 to 28 February 2011 under the grant agreement No. 30121.2009.004-2009.807]. Poznań-Katowice: Projekt MEETS.

Kropp, P., Schwengler, B. (2016). Three-Step Method for Delineating Functional Labour Market Regions. Regional Studies, 50(3), 429-445. DOI:10.1080/00343404.2014.923093. 
Misztal, S., Zioło, Z. (red.) (1998). Dorobek polskiej geografii przemysłu w badaniach ośrodków akademickich [Achievements of the Polish geography of industry in the research of academic centers]. Warszawa-Kraków. Wydawnictwo Polskiej Akademii Nauk.

Młodak, A. (2012). Statystyka metropolii polskich - problemy i perspektywy [Statistics of Polish metropolises - problems and perspectives]. Studia Regionalne i Lokalne, 2(48), 20-38.

Młodak, A. (2014). Zastosowanie metody bootstrapowej do oceny precyzji szacunków danych z badania reprezentacyjnego NSP 2011 na przykładzie dojazdów do pracy, [Application of the bootstrap method to assess the accuracy of estimates of data from the representative survey of the National Census 2011 on the example of commuting]. Wiadomości Statystyczne, 12, 38-57.

Paradysz, J. (ed.), Dehnel, G., Gołata, E., Klimanek, T., Szymkowiak, M., Witkowska, A., Witkowski, M. (2004). Statystyka [Statistics]. Poznań: Wydawnictwo Akademii Ekonomicznej w Poznaniu.

Paradysz, J. (2007). Rejestry administracyjne jako źródło zasilania w statystyce regionalnej [Administrative registers as a source in regional statistics]. In: Statystyka regionalna $w$ jednoczącej się Europie [Regional statistics in a unifying Europe]. Poznań: Internetowa Oficyna Wydawnicza Centrum Statystyki Regionalnej.

Rachwał, T. (2015). 30 lat konferencji z zakresu przemian strukturalnych przemysłu i usług oraz 15 lat „Prac Komisji Geografii Przemysłu Polskiego Towarzystwa Geograficznego” - główne problemy badawcze [30 years of the conferences on structural transformation of industry and services and 15 years of the Studies of the Industrial Geography Commission of the Polish Geographical Society - main research issues]. Prace Komisji Geografii Przemysłu Polskiego Towarzystwa Geograficznego [Studies of the Industrial Geography Commission of the Polish Geographical Society], 29(4), 145-161.

Ręklewski, M., Ryczkowski, M. (2016). The Polish Regional Labour Market Welfare Indicator and Its Links to Other Well-being Measures. Comparative Economic Research, 19(3). DOI:10.1515/cer-2016-0023.

Ryczkowski, M. (2015). Administracyjne źródła danych jako jeden z kierunków rozwoju regionalnej statystyki publicznej [Administrative sources of data as one of the directions for the development of regional official statistics]. Zeszyty Naukowe Wyższej Szkoły Gospodarki w Bydgoszczy, 7, 111-122.

Ryczkowski, M. (2016). Komparatywna analiza źródeł danych na potrzeby budowy nowoczesnego Systemu Rachunków Pracy [Comparative analysis of data sources for the needs of building a modern System of Work Accounts]. Wiadomości Statystyczne, 1(656), 1-11.

Ryczkowski, M., Stopiński, P. (2018). Labour Market Areas in Poland. Przegląd Statystyczny [oddany do druku].

Stimson, R., Mitchell, W., Flanagan, M., Baum, S., Tung-Kai, S. (2016). Demarcating Functional Economic Regions Across Australia Differentiated By Work Participation Categories, Australasian Journal of Regional Studies, 22(1), 27-57.

Stryjakiewicz, T (2001). Orientacje teoretyczno-metodologiczne w geografii przemysłu a transformacja gospodarki [Theoretical and methodological orientations in the geography of industry and the transformation of the economy]. Prace Komisji Geografii Przemysłu Polskiego Towarzystwa Geograficznego [Studies of the Industrial Geography Commission of the Polish Geographical Society], 3, 13-27.

Śleszyński, P. (2013). Delimitacja miejskich obszarów funkcjonalnych stolic województw [Delimitation of urban functional areas of the voivodeship capitals]. Przeglad Geograficzny, 85(2), 173-197.

Wdowicka, H. (2016). Analiza sytuacji na lokalnych rynkach pracy w Polsce [Analysis of the situation on the local labour markets in Poland]. Prace Naukowe Uniwersytetu Ekonomicznego we Wrocławiu, 426, 235-244.

Witkowski, M. (ed.), Szymkowiak, M., Witkowska, A. (2009). Statystyka matematyczna w zarzadzaniu [Mathematical statistics in management]. Poznań: Wydawnictwo Uniwersytetu Ekonomicznego w Poznaniu.

Wiesława Gierańczyk, Ph.D. She holds a PhD in Earth Sciences, is a graduate of the Faculty of Geography at the Nicolaus Copernicus University in Torun. She is a researcher, now the acting director of the Statistical Office in Bydgoszcz. She has completed postgraduate studies in financial management and marketing, statistical 
methods for the analysis and presentation data, science and research project manager. She is the author or a co-author of many reference studies and a reviewer of academic papers published in national and international journals. Her main interest areas include innovation, geography of industry and regional development.

\section{Address:}

Statistical Office in Bydgoszcz

ul. Ks. Stanisława Konarskiego 1-3, 85-066 Bydgoszcz, Poland

e-mail:w.gieranczyk@stat.gov.pl

Maciej Ryczkowski, Ph.D. Statistical Office in Bydgoszcz and Nicolaus Copernicus University, Faculty of Economic Sciences and Management. In 2003, Maciej Ryczkowski graduated from the I Secondary School of Cyprian Kamil Norwid in Bydgoszcz with mathematical-computer studies specialisation. Next, he studied economics at the Nicolaus Copernicus University in Torun with specialisation in international finances. He graduated in 2008. Four years later he defended his doctoral thesis: 'Monetary Policy of Milton Friedman and Direct Inflation Targeting Strategy'. Currently he is an assistant professor in the Department of Economics of the Faculty of Economic Sciences and Management of the Nicolaus Copernicus University in Toruń, and a specialist in the Statistical Office in Bydgoszcz. In the years 1999-2003, he was a laureate and finalist of many mathematical competitions. His academic interests focus on monetary policy, in particular on the importance of money in economies, as well as on labour market policy.

\section{Address:}

Statistical Office in Bydgoszcz

ul. Ks. Stanisława Konarskiego 1-3

85-066 Bydgoszcz, Poland

e-mail:m.ryczkowski@stat.gov.pl 